\title{
Prospective memory in students with learning disabilities
}

\author{
Razaan M. Alotaibi*, Kowthar J. Ali \\ Imam Abdulrahman Bin Faisal University - College of Science and Humanities, \\ Dammam, Saudi Arabia
}

Introduction. The importance of memory is not restricted to remembering the knowledge and experiences of the past retrospective memory (RM), but also to remember what an individual must accomplish in the future prospective memory (PM). Objectives. The aim of this study was to identify RM and PM levels in students with learning disabilities (LD) according to some variables (gender, grade) and to identify the differences between the two types of memories. Methods. The study followed the comparative descriptive statistics. The study sample consisted of 37 male and female students with LD in middle school. The Prospective and Retrospective Memory Questionnaire (PRMQ) was used in this study. Results. The results include the following: a statistically significant decrease from the average in PM and RM levels in students with LD, the existence of statistically significant differences between PM and RM in students with LD for the RM, the presence of statistically significant differences in the PM and RM according to the gender variable for females, and the presence of statistically significant differences in PM and RM according to the grade variable for the third grade of middle school. Conclusion. Students with LD may suffer from a decrease in their capacity to remember in the future, which causes many difficulties in daily life. We guide teachers to use external aids for students with LD (such as writing notes) to help students remember performing their tasks.

Keywords: prospective memory, retrospective memory, learning disabilities, middle school

\section{Introduction}

Prospective memory (PM) is known as "remembering to do things at some future point in time. Thus, remembering that you have to attend a particular function or carry out some personal task at some future point" (Heffernan \& Ling, 2001. p 321). And based on what Zimmermann and Meier

${ }^{*} \mathrm{PhD}$ student

Correspondence: Razaan Alotaibi, razaanm@hotmail.com 
(2010) indicated, the retrospective memory (RM) is one of the components of the PM, where the PM is concerned with remembering the task that must be performed, and the RM is concerned with remembering the content of this task, and the success of performance in PM depends on both RM and PM. Walter and Meier (2014) indicate that the importance of PM is evident in that it enables us to plan time in an economical way. Also, it provides an opportunity to live an independent life, and PM clearly affects our reputation and our self-esteem. For example a person may be seen as a confident and organized person because of good PM, and a person may lose the confidence of others in him if his PM is weak. Academic success depends to a large extent on a student's capacity to remember performing tasks (Anwar, 2005).

As it is known, students with learning disabilities (LD) suffer from memory disorders, and they often forget their tools and books, do not complete their homework and forget what the teacher asked them on the previous day. LD are explained according to neuropsychological theory in the presence of a minimal brain alteration, and Abdul-Qawi (2017) explains this alteration as a difference in the size and function of parts of the brain. Mioni et al. (2014) indicate that there is a relationship between executive functions and brain injuries, especially the frontal lobe, and disturbances in PM. The importance of measuring RM and PM levels of students with LD helps in self-reliance and independence, and this study may help to identify more of their strengths and weaknesses. This helps to provide integrated services to them, ensure their ability to perform tasks on time, and build independent and accomplished people.

There are no accurate statistics on the prevalence of LD as it differs with the different measuring scale (test) used. Nonetheless, LD are considered as one of the largest in categories in special education cases. It constitutes 4-5\% of children 6-17 years old. In the Kingdom of Saudi Arabia, according to Metwally and Al-Qahtani (2016), the prevalence of LD was $4.5 \%$ and it was more prevalent in males.

Several studies have been conducted to study the PM of people with LD by comparing them with a group of typical individuals, equal in age and IQ. For example, time-based PM (Smith-Spark et al., 2016) and event-based PM (SmithSpark et al., 2017) were studied in two groups of participants - those with selfdeclared dyslexia, and adults without dyslexia. Khan (2014) found that metamemory affects both PM and RM in children with dyslexia much more than in the control group. Studies have been conducted in typical population (Anwar, 2005; Cejudo et al., 2019; Crawford et al., 2003; Riess et al., 2016; Smith et al., 2010) and their results varied in determining the presence of differences in PM according to age or gender. According to Riess et al. (2016) research results, studies dealing with gender differences in PM are various, and these variations result from the diversity of the samples. For example, differences between men and women in different age groups are not the same. 
We note from the above that research studies on people with LD in the field of PM are scarce. Therefore, this study was conducted to expand the study of PM among people with LD. Middle school was chosen to measure the PM of students with LD because this age range was not covered by previous studies. As indicated by Smith-Spark et al. (2017), it is expected that in this period in adolescence individuals start behaving responsibly. This study aims to reveal RM and PM levels of students with LD and detect differences between the two (RM-PM) memories, according to the variables of gender and grade.

\section{Methods}

This study followed the comparative descriptive statistics. The purposive sampling was used from the city of Dammam Saudi Arabia from middle school students who were classified according to the Ministry of Education within the category of LD (dyslexia and dyscalculia). The Ministry of Education selection of LD cases works as follows. Teachers or guardians are the first to notice any signs of discrepancy between a child's cognitive abilities and his/her academic level. The diagnosis of such cases is supervised by a complete team of experts, and it is based on DSM-5 criteria (APA, 2013). Any mental or behavioral disorders or environmental factors have to be excluded to prove that standard education methods are either unsuitable or less effective for the student. The sample consisted of 37 students ( 27 males and 10 females). There were 16 twelve-year-old students from the first year of middle school, 10 thirteen-year-olds from the second year, and 11 fourteen-year-old students from the third year of middle school. The sample included all community members except one girl who did not attend school during the application period and three incomplete questionnaires were excluded.

The Prospective and Retrospective Memory Questionnaire PRMQ, prepared by Smith et al. (2000) was used in this study. This tool is a questionnaire that consists of 16 statements designed to measure PM. All statements are negative statements and the responses range from 1 to 5 (always $=1$, usually $=2$, sometimes $=3$, rarely $=4$, never $=5$ ). To reach the result, the Sign test was used to compare the student means. The value (sometimes: 3 ) had a statistical significance as the mean value which indicates above, at, or below mean. The internal consistency of the total scale, as well PM and RM subscales, as measured by Cronbach's alpha, was acceptable (Crawford et al., 2003). In this study, Cronbach's alpha was also verified, and it was (.87), which is a high percentage, making it suitable for application. To implement this study, special education departments were contacted, and permission was obtained from the Ministry of Education. After that, we visited schools, applied the questionnaire to the sample, entered the obtained data into the computer, and finally analyzed the data using the Statistical Package for Social Sciences program SPSS Version No. 24 to get the results of the study. Descriptive statistics were used to extract averages and Cronbach's alpha to measure stability, the Sign test to find out if the averages of responses have reached the medium range or not, the Mann-Whitney test to find differences between 
the two types of memories and the differences according to the gender variable, the Kruskal-Wallis test to find differences according to the grade variable, and the Post Hoc Duncan's Test to determine the direction of the differences.

\section{Results}

To identify RM and PM levels in students with LD, averages were extracted and the Sign test was performed. The results are shown in Table 1.

\section{Table 1}

Shows the Averages of The Students' Responses to The Questionnaire and the Score of the Sign Test

\begin{tabular}{lcccc}
\hline The Domains of the Questionnaire & Mean & $S D$ & $Z$ & $p$ \\
\hline Retrospective Short-Term Memory & 2.90 & 1.38 & 1.11 & .047 \\
Retrospective Long-Term Memory & 3.24 & 1.34 & 1.32 & .188 \\
Prospective Short-Term Memory & 2.45 & 1.21 & 5.32 & $\leq .000$ \\
Prospective Long-Term Memory & 3.01 & 1.42 & 0.18 & .853 \\
PRMQ total scale & 2.90 & 1.37 & 2.59 & .010 \\
\hline
\end{tabular}

To reveal the differences between RM and PM, averages were calculated, and the Mann-Whitney test was used for two independent samples. The results are shown in Table 2.

\section{Table 2}

Shows the Arithmetic Averages, (Z) Value and its Statistical Significance for the Difference Between the Averages of RM and PM

\begin{tabular}{lccccc}
\hline Type & Mean & $S E$ & Average Ranks & $Z$ & $p$ \\
\hline RM & 3.07 & 0.08 & 317.37 & -3.04 & \multirow{2}{*}{002} \\
PM & 2.73 & 0.08 & 275.63 & & \\
\hline
\end{tabular}

\section{Table 3}

Shows the Arithmetic Averages, (Z) Value and its Statistical Significance for the Difference Between the Averages of RM and PM According to the Type Variable

\begin{tabular}{llccccc}
\hline Type of memory & Gender & Mean & $S E$ & Average Ranks & $Z$ & $p$ \\
\hline \multirow{2}{*}{ RM } & Male & 2.93 & 0.09 & 263.69 & \multirow{2}{*}{2.44} & \multirow{2}{*}{.038} \\
& Female & 3.46 & 0.16 & 300.01 & & \\
PM & Male & 2.60 & 0.09 & 135.98 & -3.08 & \multirow{2}{*}{.002} \\
\hline & Female & 3.21 & 0.17 & 170.06 & & \\
\end{tabular}


In order to reveal the differences in RM and PM according to the gender variable, the arithmetic averages were extracted, and the Mann-Whitney test for two independent samples was used to detect the differences between the averages. The results are shown in Table 3 .

In order to detect the differences in the RM and PM according to the grade variable, the averages were extracted and the Kruskal-Wallis Test was used to detect the differences between the averages. The results are shown in Table 4.

\section{Table 4}

Shows the Arithmetic Averages, $\chi^{2}$ Value and its Statistical Significance for the Difference Between the Averages of RM and PM According to the Grade Variable

\begin{tabular}{llccccc}
\hline Type of Memory & Grade & Mean & SE & Average Ranks & $\chi^{2}$ & $p$ \\
\hline \multirow{3}{*}{ RM } & First & $2.72^{\mathrm{c}}$ & 0.12 & $123.95^{\mathrm{c}}$ & & \\
& Second & $3.14^{\mathrm{b}}$ & 0.16 & $148.01^{\mathrm{b}}$ & 18.45 & .000 \\
& Third & $3.54^{\mathrm{a}}$ & 0.13 & $173.09^{\mathrm{a}}$ & & \\
\multirow{2}{*}{ PM } & First & $2.52^{\mathrm{c}}$ & 0.11 & $135.88^{\mathrm{c}}$ & & \\
& Second & $2.75^{\mathrm{b}}$ & 0.14 & $151.35^{\mathrm{b}}$ & \multirow{2}{*}{6.15} & .046 \\
& Third & $3.02^{\mathrm{a}}$ & 0.16 & $164.27^{\mathrm{a}}$ & & \\
\hline
\end{tabular}

Note. The letters a, b, c are the results of Duncan's test which indicates the difference (rank) between the groups with a as first, $\mathrm{b}$ as second, and $\mathrm{c}$ as third.

\section{Discussion}

The results of this study indicated that the RM and PM levels of students with LD decreased from the average. This result is consistent with the study of Khan (2014), which showed that people with dyslexia performed worse than typical population on the PRMQ questionnaire. Smith-Spark et al. (2016) and Smith-Spark et al. (2017), measured PM by tasks, and showed that adults with dyslexia performed worse in PM tasks compared to typical population. Previous studies compared dyslexic and typical population in PM, and found that the performance of dyslexic people was worse than that of typical population, indicating a decrease in their PM. This result differs with the second method of measurement in Smith-Spark et al. (2017), where the results of the questionnaire showed no differences between the typical population and those with dyslexia.

This result is attributed to the fact that students with LD have disorders in psychological processes (attention - perception - memory). The origin of the deficiency in PM according to Smith-Spark. (2018) is due to several reasons, including poor verbal memory and their problems with perception of time, which limits their ability to perform tasks at the right time. It is important to 
recommend that teachers use external aids to help students with LD remember to perform their tasks and bring their required tools.

The results also indicated that there are differences among students with LD in RM, and this result is due to what Abu Jabal \& Al Rabee' (2018) indicated that PM needs more effort in coding and retrieval from RM, and people with LD - as it is known - suffer from memory disturbances, including disturbances in the memory stages of coding, storing and retrieval. That may be the reason for their low PM. It is recommended to pay attention to training the RM of students with LD and to teach them strategies that help with RM, as RM is a major component of PM.

The results of the study also showed female students' superiority in RM and PM. This result partly agreed with a study (Riess et al., 2016) that indicated the existence of differences in event-based PM for females and differed with the results of the studies (Anwar, 2005; Crawford et al., 2003) whose results showed no differences in RM and PM according to gender. This result is attributed to the fact that the research sample is still in the growth stage, which is characterized by the progress of females over males in maturity, either physical or mental, including attention, memory, abstract thinking etc. The skills of female students develop faster compared to male students, as females bear more responsibility than males in the examined community, by helping their mothers at home, caring for younger siblings and others, which helps increase their experiences in $\mathrm{PM}$. The fact that the environment can reinforce and stimulate the development of PM is also mentioned by Badawi (2016). In addition, most of the statements of the questionnaire were about social situations, and females excel over males in this area and pay more attention to it. We recommend intensifying memory training for male students to increase their capacity to remember.

The results also showed that the third year middle school students outperformed in RM and PM. This result is in accordance with Cejudo et al. (2019), who indicated the superiority of a larger group of 10-11 year-olds over a group younger than 6-7 years of age performing PM tasks, and Smith et al. (2010), who indicated the superiority of a youth group over two groups of children in performing the PM task. On the other hand, this result differs from Crawford et al. (2003), who showed that there was no effect of age on the PRMQ scores. This result is attributed to the fact that the target sample is still in the early stage of adolescence when their mental abilities mature, as evidenced by a better memory and fewer errors in older students. In addition, as they get older, they become more independent of their parents who assign them different tasks through which they gain experience and practice their PM. Thus, attention should be paid to training students' memory from early grades where memory performance is lower. 


\section{Conclusion}

This study measured PM of students with LD in both its Prospective and Retrospective components. The results show that students with LD may have difficulties in PM, especially in short-term memory as well as RM, that male students may suffer more than female students, and that younger students may be more likely to have difficulties than older students. We encourage more research in this area to help provide better services for students with LD.

\section{Limitation}

The main limitation of this study is that no comparison group was used. In addition, the sample is small due to the limited number of schools that apply LD programs.

\section{Acknowledgment}

We thank the Eastern Province Education Department for their cooperation in facilitating the implementation of this study in schools.

\section{References}

Abdul-Qawi, S. (2017). Neuropsychology foundations and assessment methods. AngloEgyptian Bookshop.

Abu Jabal, A .Y., \& Al Rabee', K. F. (2018). The retrospective and prospective memory according gender, age and mental imagery. [Master's Thesis, Alyarmook University]. Dar AlMandumah. http://search.mandumah.com/Record/988802

American Psychiatric Association (APA). (2013). Diagnostic and Statistical Manual of Mental Disorders, 5th edition (DSM-5). Washington, DC: American Psychiatric Publishing.

Anwar, M. A. (2005). Gender differences in efficiency of childrens episodic memory, in the condition of using motor subjective performed strategy. Egyptian Journal of Psychological Studies, 15(49), 193-246.

Badawi, A. Z. (2016). Cognitive psychology between theory and practice: Prospective memory. Modern Book Hous.

Cejudo, A. B., McDaniel, M. A., \& Bajo, M. T. (2019). Event versus activity-based cues and motivation in school-related prospective memory tasks. PloS One, 14(4), Article e0215845. https://doi.org/10.1371/journal.pone.0215845

Crawford, J., Smith, G., Maylor, E., Della Sala, S., \& Logie, R. (2003). The Prospective and Retrospective Memory Questionnaire (PRMQ): Normative data and latent structure in a large non-clinical sample. Memory, 11(3), 261-275. https://oi. org/10.1080/09658210244000027

Heffernan, T. M., \& Ling, J. (2001). The impact of Eysenck's extraversion-introversion personality dimension on prospective memory. Scandinavian Journal of Psychology, 4(42), 321-325. https://doi.org/10.1111/1467-9450.00243

IBM Corp. (2016). IBM SPSS Statistics for Windows, Version 24.0. IBM Corp. 
Khan, A. (2014). An investigation into prospective memory in children with developmental dyslexia. Frontiers in Psychology, 5, Article 1308. https://doi.org/10.3389/ fpsyg.2014.01308

Metwally, F. L., \& Al-Qahtani, S. M. (2016). Learning difficulties for innovators and gifted people. Anglo-Egyptian Library.

Mioni, G., McClintock, S. M., \& Stablum, F. (2014). Understanding, assessing and treating prospective memory dysfunctions in traumatic brain injury patients. In F. Sadaka (Ed.), Traumatic brain injury (pp. 401-436). BoD - Books on Demand

Riess, M., Janoszczyk, K., Niedźwieńska, A., \& Rendell, P. G. (2016). Gender differences in prospective memory in young and older adults. Roczniki Psychologiczne, 19(4), 803-812. http://dx.doi.org/10.18290/rpsych.2016.19.4-5en

Smith, G., Della Sala, S., Logie, R. H., \& Maylor, E. A. (2000). Prospective and retrospective memory in normal aging and dementia: A questionnaire study. Memory, 8(5), 311321. https://doi.org/10.1080/09658210050117735

Smith, R. E., Bayen, U. J., \& Martin, C. (2010). The cognitive processes underlying event-based prospective memory in school-age children and young adults: A formal model-based study. Developmental Psychology, 46(1), 230-244. https://doi. org/10.1037/a0017100

Smith-Spark, J. H. (2018). A review of prospective memory impairments in developmental dyslexia: Evidence, explanations, and future directions. The Clinical Neuropsychologist, 32(5), 816-835. https://doi.org/10.1080/13854046.2017.1369571

Smith-Spark, J. H., Zięcik, A. P., \& Sterling, C. (2016). Time-based prospective memory in adults with developmental dyslexia. Research in Developmental Disabilities, (4950), 34-46. https://doi.org/10.1016/j.ridd.2015.11.006

Smith-Spark, J. H., Zięcik, A. P., \& Sterling, C. (2017). The event-based prospective memory of adults with developmental dyslexia under naturalistic conditions. Asia Pacific Journal of Developmental Differences, 4(1), 17-33. https://doi.org/10.3850/ S2345734117000036

Walter, S., \& Meier, B. (2014). How important is importance for prospective memory? A review. Frontiers in Psychology, 5, Article 657. https://doi.org/10.3389/ fpsyg.2014.00657

Zimmermann, T. D., \& Meier, B. (2010). The effect of implementation intentions on prospective memory performance across the lifespan. Applied Cognitive Psychology, 24(5), 645-658. https://doi.org/10.1002/acp.1576

\title{
Prospektivna memorija kod učenika s teškoćama u učenju
}

\author{
Razaan M. Alotaibi, Kowthar J. Ali \\ Univerzitet Imam Abdulrahman Bin Faisal - Fakultet za nauku i humanistiku, \\ Damam, Saudijska Arabija
}

Uvod: Značaj pamćenja nije ograničen samo na prisećanje znanja i iskustava iz prošlosti - retrospektivna memorija (RM), već obuhvata i pamćenje onoga što bi pojedinac morao da ostvari u budućnosti - prospektivna memorija (PM). Ciljevi: Cilj ovog istraživanja je da utvrdi nivo RM i PM kod učenika s teškoćama u učenju u odnosu na pol i razred 
koji pohađaju, kao i da ustanovi razlike između ova dva tipa pamćenja. Metode: U ovom istraživanju primenjena je komparativna deskriptivna statistika. Istraživački uzorak se sastoji od 37 srednjoškolaca s teškoćama u učenju, oba pola. Procena je izvršena primenom upitnika za PM i RM (The Prospective and Retrospective Memory Questionnaire). Rezultati: Dobijeni rezultati pokazuju da su kod učenika s teškoćama u učenju PM i RM značajno ispod proseka, s tim što su oba oblika pamćenja statistički značajno razvijenija kod ispitanika ženskog pola, kao i kod učenika trećih razreda, u poređenju sa dečacima i učenicima ostalih razreda. Zaključak: Učenici s teškoćama u učenju mogli bi da se suoče sa smanjenjem kapaciteta za pamćenje u budućnosti, što ima za posledicu poteškoće u svakodnevnom životu. Stoga se nastavnici usmeravaju da koriste spoljašnja pomoćna sredstva, poput pravljenja zabeleški, kako bi se pomoglo učenicima s teškoćama u učenju da se prisete kako da urade svoje zadatke.

Ključne reči: prospektivna memorija, retrospektivna memorija, teškoće u učenju, srednja škola 